\title{
Preparation of Ultrafine Barium Titanate Powder by Slurry Spray Pyrolysis
}

\author{
Jong Ho Lee $\dagger$, Kang Heon Hur, and Jung Soo Lee
}

LCR Division, Samsung Electro-Mechanics Co., Ltd., Suwon 443-743, Korea

(Received November 14, 2008; Accepted December 8, 2008)

\section{슬러리 분무열분해에 의한 초미립 티탄산 바륨 분말 제조

\author{
이종호 $\cdot$ 허강헌 $\cdot$ 이정수
} \\ 삼성전기 주식회사 $\mathrm{LCR}$ 사업부 \\ (2008년 11월 14일 접수; 2008년 12월 8일 승인)}

\begin{abstract}
A remarkable improvement of the productivity in barium titanate by slurry spray pyrolysis process was realized by supplying solid source slurry into the rector. The produced barium titanate powders showed uniform powder properties, and reproducibility with higher tetragonality in the range of $80 \sim 200 \mathrm{~nm}$, case by case. The secondary calcination experiments of the as-prepared powders by spray pyrolysis revealed that the powders as-prepared over $700^{\circ} \mathrm{C}$ showed perfectly different behavior with the lower temperature's ones and the solid state reaction's case. The result was discussed in terms of the reaction mechanism based on the activation energy analysis.
\end{abstract}

Key words : Spray pyrolysis, Barium titanate, MLCC, Tetragonality, Reaction mechanism

\section{1. 서 론}

최종 세라믹 제품의 성능은 중간 제조 과정에도 영향 을 받지만, 특히 출발 물질인 세라믹 분말의 선택에 의해 좌우된다고 해도 과언이 아닐 만큼 세라믹 분말의 성질 은 매우 중요하다. 더욱이, 최근 칩부품의 소형화, 고기능 화 요구에 의한 박층화 및 고적층화가 필요하게 됨에 따 라 더욱 작은 입자크기를 갖는 모재 분말이 요구되고 있 다. ${ }^{1)}$ 이와 같은 경향은 적층형 세라믹 콘덴서(MLCC)의 경우도 마찬가지로 적용되는데, 유전층에 사용되는 모재 의 입자가 작아질수록 유전율이 감소되고, core-shell을 구 현하기 위한 첨가상들도 함께 미립화되어야 하기 때문에 제품 적용을 위해서는 여러 가지 기술적 문제의 해결이 필수적이다. 이와 같은 상황에서 절연저항 및 온도특성을 확보하기 위해서는 미립에서도 우수한 특성을 가지는 모 재의 개발과 더불어 첨가제들의 미립화 및 분산에 대한 연구가 차세대 MLCC 개발에 있어서 높은 우선순위를 가 지게 된다.

이상적인 세라믹 분말의 물리화학적 성질로는, 미세한 입경과 균일한 입도분포, 균일한 입자의 형상, 응집의 최 소화, 화학적 고순도, 화학적 조성과 결정상의 균일성 등

${ }^{\dagger}$ Corresponding author : Jong Ho Lee

E-mail : jh205.lee@samsung.com

Tel : +82-31-210-3187 Fax :+82-31-300-7900(1854)
을 들 수 있다. $\mathrm{BaTiO}_{3}$ 분말은 여러 가지 방법으로 제조 될 수 있으며, 그 중 대표적인 방법으로는 고상법, 공침 법, sol-gel법, 수열합성법 등이 있다. ${ }^{2-5)}$ 이 중, 고상법은 생산성 및 경제성 측면에서 월등한 장점을 가지나 평균 입도 미립화 부분에서 한계가 있으며 화학적 균일도가 낮 다는 단점 때문에, 상기한 요구조건을 만족시키기 어렵다. 공침법은 여러 가지 서로 다른 이온들을 수용액 혹은 비수용액에서 동시에 침전시키는 방법으로서, 불용성의 수산염이나 탄산염 혹은 옥살산염 등을 미세하게 혼합 분 산된 상태로 동시에 석출시키는 방법이다. 이 경우, 음이 온 불순물도 함께 공침될 수 있는데, 이러한 불순물은 격 자의 결함으로 입자에 섞이거나 분말 표면에 흡수될 가 능성이 있다. 이러한 불순물들은 세척과정을 통하여 제거 하기가 매우 어렵기 때문에 다음 단계인 성형이나 제품 의 성능에 악영향을 미친다.

Sol-gel법에 의한 세라믹 분말 제조법은 생성된 분말의 우수한 기계적 물성과 높은 화학적 순도 때문에 점차 그 응용 영역이 확대되고 있는 추세이나, 고가의 원료를 사 용하기 때문에 경제성이 떨어지는 단점이 있다.

또한, 수열합성법은 균질한 수용액이나 전구체 현탁액 을 승온, 승압하여 처리하는 방법이다. 수열합성법의 주 요 장점은 하소 과정없이 탈수된 결정성 분말을 직접 만 들 수 있으며, 저렴한 출발 물질을 사용할 수 있다는 점 이지만, 입자 형성 과정 중에 입자 내에 포획된 수산화기 로 인해 최종 입자 내에 기공 결함이 발생된다는 단점을 


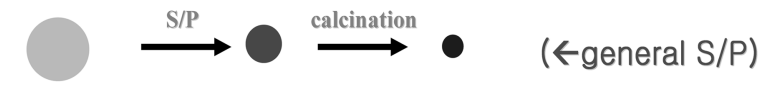

II.
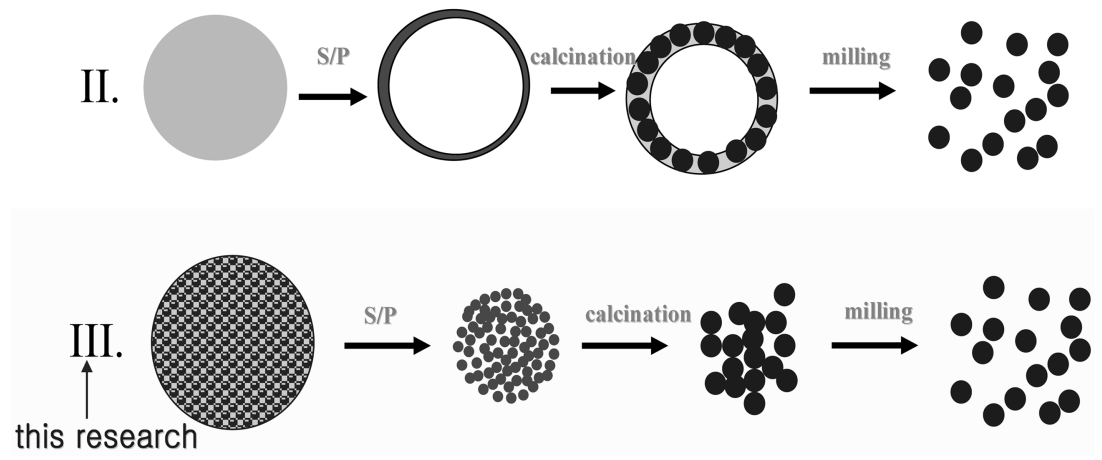

Fig. 1. Two types and new type of preparation of barium titanate powder by spray pyrolysis.

가지고 있다.

본 연구에서 사용된 분무열분해법은 전구물질이 용해 된 분무액을 초음파 진동자나 노즐 등의 액적발생기를 이 용해 액적화하여 고온의 반응기 내를 통과시켜 입자를 제 조하는 방법이다. 분무열분해법은 출발물질의 선택이 자 유로워 저렴한 원료를 사용할 수 있다는 점과, 조성의 정 밀한 제어가 용이하여 조성 균일성 및 균일한 도핑을 이 룰 수 있고, 공정 자체가 회분식 공정이 아닌 연속 공정 이라는 장점을 가지고 있다. 하지만 액적 발생기의 성능 한계 등으로 인해 생산성이 다른 공정에 비해 현격히 떨 어지기 때문에 산업용보다는 실험실 규모에서 주로 연구 되어져 왔다. 이러한 분무열분해 공정의 한계를 극복하기 위해서, 본 연구에서는 분무액으로서 용액이 아닌 나노크 기의 고형분을 분산시킨 슬러리를 사용함으로써 생산성 을 획기적으로 향상시키고자 하였다. Fig. 1에 분무열분 해에 의해 티탄산 바륨계 분말을 제조하는 방법에 대한 개념도를 도시하였다.

Fig. 1 의 type I은 일반적인 분무열분해 공정으로서 분 무액은 용액을 사용하며, 하나의 액적으로부터 하나의 입 자를 얻는 방법이다. 따라서, 최종 얻어지는 분말의 입경 은 최초 분무액의 농도와 발생 액적의 크기에 직접적으 로 좌우된다. 즉, 제조 분말의 입경은 분무액 농도의 $1 / 3$ 승에 비례하며, 액적 크기의 1 승에 비례하게 된다. 따라 서, 이 방법으로 미립의 분말을 얻기 위해서는 농도를 극 단적으로 낮추거나 초음파 진동자 등의 되도록이면 미세 한 액적을 발생시킬 수 있는 장치를 사용해야만 한다. 따 라서, 이 방법으로 수백 $\mathrm{nm}$ 급의 분말을 제조하는데 있어 서 액적발생기 1 개 당 수 수십 $\mathrm{g} / \mathrm{h}$ 의 낮은 생산성을 갖 는다. Type II는 type I과 같이 용액을 분무액으로 사용하 지만, 구연산 등과 같은 유기첨가제를 첨가해서 분무열분 해에 의해 합성되는 분말을 극단적으로 속이 빈 입자로 제조하여, 하소공정 중에 나노 두께의 얇은 shell로부터
여러 개의 일차 입자를 성장시키는 방법이다. ${ }^{6)}$ 이 방법은 하나의 액적으로부터 여러 개의 입자를 제조하는 방법이 기 때문에 최종 제조되는 입자의 크기가 최초 발생되는 액적의 크기나 분무액의 전구체 농도에 크게 영향을 받 지 않는다. 따라서, 미세한 액적을 발생시키는 장치를 굳 이 사용할 필요가 없으며, 발생되는 액적은 미세하지 않 다 할지라도 노즐과 같은 액적 발생량이 큰 장치를 사용 하는 것이 가능하여, type I 보다는 훨씬 높은 생산성을 갖는다. 하지만, 출발물질로 사용되는 용해 가능한 $\mathrm{Ti}$ 전 구체가 알콕사이드나 염화물 등으로 매우 제한적이고 고 가일 뿐 아니라 공기 중에서 불안정하고, 전구체의 용해 도 한계 때문에 여전히 생산성에 한계를 가진다. 이 방법 은 액적발생기 1 개당 대략 $100 \mathrm{~g} / \mathrm{h}$ 의 생산성을 갖는다.

Type III의 방법은 일반적인 분무열분해법의 낮은 생산 성을 극복하기 위하여 본 연구에서 시도된 방법으로서, 용액을 분무하는 기존 방식에서 탈피하여 나노 크기의 고 상원료를 분산한 슬러리를 분무하여 반응기에 주입하는 방법이다. 즉, 고상법에서 사용하는 저렴한 원료 물질과 분무열분해법을 접목하는 방법이다. 이 경우, 용액을 사 용하는 경우보다 분자 수준에서의 혼합도는 떨어지지만, 나노 원료물질의 분산기술이 점점 발전되어 왔기 때문에 나노 수준의 혼합도를 가질 수 있으며, 값싼 원료 및 분 무액 내의 원료 함유량이 높기 때문에 경제성 및 생산성 이 type I, II에 비해 월등히 높게 된다. 본 개발 방법으로 는 액적발생기 1 개당 $1 \sim 1.5 \mathrm{~kg} / \mathrm{h}$ 정도로서 type II에 비하 여 10 15배 이상의 높은 생산성 확보가 가능하다.

\section{2. 실험 방법}

Barium titanate 분말제조를 위한 $\mathrm{Ba}$ 및 $\mathrm{Ti}$ 전구 물질로 서 각각 $\mathrm{BaCO}_{3}, \mathrm{TiO}_{2}$ 를 사용하였으며, 각각의 제조원 및 주요 물성은 Table 1과 같다. 분산제로는 Sannop $5468 \mathrm{C}$ 
Table 1. Raw Materials for Preparation of Barium Titanate Powder

\begin{tabular}{cccc}
\hline $\begin{array}{c}\text { Raw } \\
\text { material }\end{array}$ & Supplier & Purity & $\begin{array}{c}\text { Specific } \\
\text { surface area }\end{array}$ \\
\hline $\mathrm{BaCO}_{3}$ & Solvay & $99.9 \%$ & $20 \mathrm{~m}^{2} / \mathrm{g}$ \\
$\mathrm{TiO}_{2}$ & Showa denko & $99.7 \%$ & $45 \mathrm{~m}^{2} / \mathrm{g}$ \\
\hline
\end{tabular}

(Sannop Co.)를 원료파우더 총질량 대비 $3 \mathrm{wt} \%$ 를 사용하 였으며, 슬러리 혼합은 Netzsch(LMZ10) 밀링 장비를 이 용하여 분쇄와 혼합을 하였다. $\mathrm{Ba}_{\mathrm{m}} \mathrm{TiO}_{3}$ 의 조성은 $\mathrm{m}=1.005$ 로 고정하였으며, 8시간 이상 혼합된 슬러리에서 시료를 채취하여 $\mathrm{XRF}(\mathrm{Rigaku}, \mathrm{ZSX})$ 검증을 통해 조성을 보정하 였다.

분쇄와 혼합 및 조성 보정이 완료된 혼합 슬러리를 분 무액으로 사용하여 Fig. 2에 도시한 분무열분해 반응기를 통해 파우더를 합성한 후, 하소 공정을 통해 원하는 입경 을 가지는 barium tatanate 분말을 제조하였다. 분무열분해 공정에서 운반 기체로는 $\operatorname{air}(100 \mathrm{~L} / \mathrm{min})$ 를 사용하였고, 액 적 발생기로는 이류체 노즐 $($ 노즐경 $\phi 0.3 \mathrm{~mm})$ 을 사용하였 다. 또한, 원료 주입속도는 $4.5 \mathrm{~L} / \mathrm{h}$ 로 고정하였으며, 반응 기 온도는 $500 ~ 1000^{\circ} \mathrm{C}$ 범위에서 변화시켜 가며 제조하였 다. 분무열분해 반응기의 반응부의 직경은 $250 \mathrm{~mm}$ 이며 길이는 $1500 \mathrm{~mm}$ 이다.

합성된 barium titanate 분말은 고온의 반응기를 통과하 였지만 짧은 체류시간으로 인해 미반응 barium carbonate
도 미량 존재하며, 입자 성장 및 결정성도 확보되지 않으 므로 하소 공정이 필요하다. 하소 공정은 box furnace에서 $800^{\circ} \mathrm{C}$ 이상의 온도에서 수행하였으며, 승온속도는 $5^{\circ} \mathrm{C} / \mathrm{min}$, 유지 시간은 1시간으로 고정하였다.

합성 및 하소 공정을 거쳐 제조된 barium titanate 분말은 $\mathrm{FE}-\mathrm{SEM}(\mathrm{Jeol}, \mathrm{JSM}-6700 \mathrm{~F})$ 을 이용해 입자형상 및 일차입자 의 크기를 관찰하였고, XRD(Rigaku, Rint $2200 \mathrm{HF}+$ )를 통해 결정상 및 결정성을 평가하였으며, BET(Mircromeritics, Tristar3000)를 이용해 비표면적을 측정하였다. 또한 TGA (TA Instrument, DSC2010)에 의한 열분석을 통해서 반응 온도 구간 및 반응 메카니즘을 규명하고자 하였다.

\section{3. 결과 및 고찰}

\section{1. 합성 온도 및 하소 온도의 영향}

분무열분해 반응기를 통해 합성된 미하소 분말은 대략 $30 \mathrm{~nm}$ 정도의 일차입자들이 수 $\mu \mathrm{m}$ 의 크기로 응집되어 있 는 상태이다(Fig. 3(a)). 이는 분무액이 노즐을 통하여 대 략 $10 \mu \mathrm{m}$ 의 액적 단위로 반응기에 주입되므로, 하나의 액 적에 포함되어 있던 용매가 건조되고, 이에 포함되어 있 는 원료 입자들이 하나의 이차입자를 형성한 것이다. 즉, 각각의 액적은 열 및 물질의 확산 거리가 짧아 균일한 반 응이 빠르게 진행될 수 있는 일종의 마이크로 반응기라 볼 수 있으며, 반응기를 통과하는 동안, 건조 및 $\mathrm{TiO}_{2}$ 입 자를 핵으로 하여 반응이 빠르고 균일하게 일어나게 된

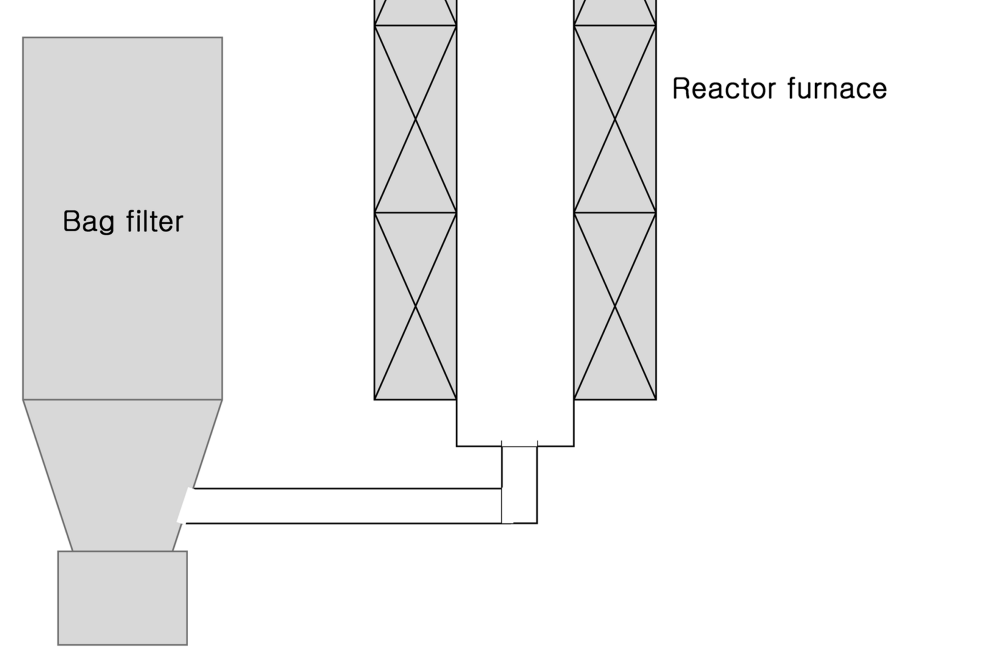

Fig. 2. Schematic diagram of spray pyrolysis reactor. 

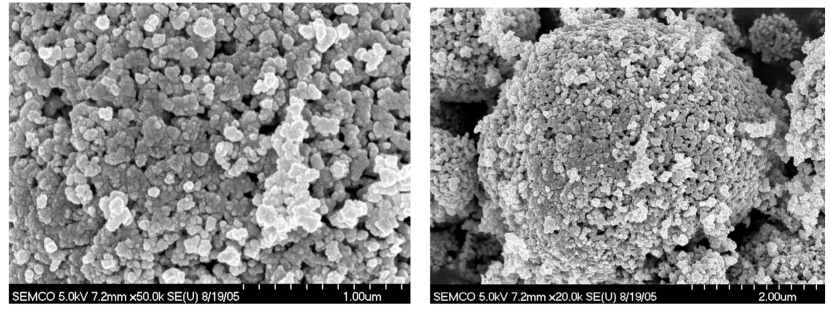

(a) as-prepared
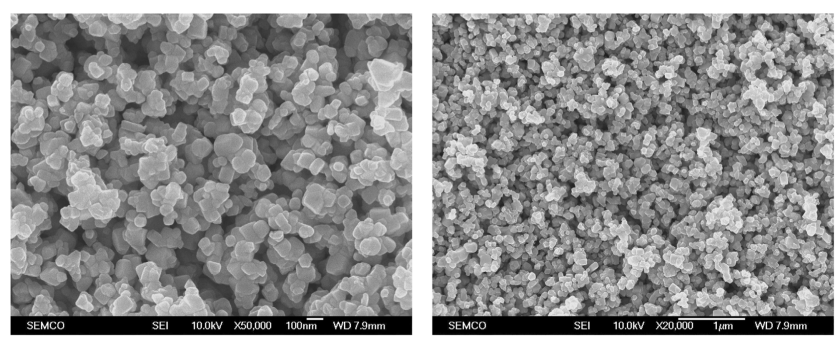

(b) $T_{\text {calcination }}=850^{\circ} \mathrm{C}$
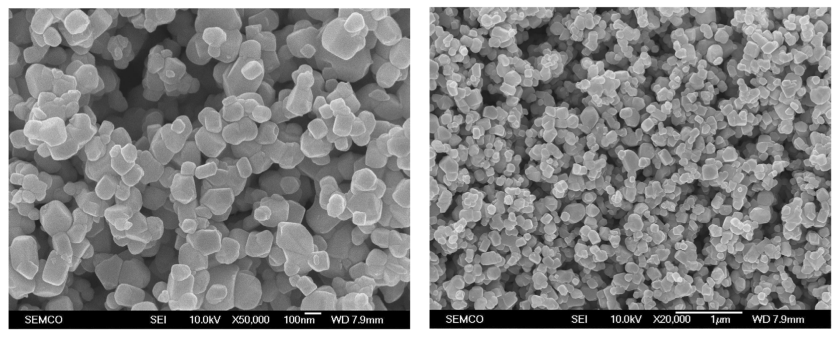

(c) $T_{\text {calcination }}=950^{\circ} \mathrm{C}$
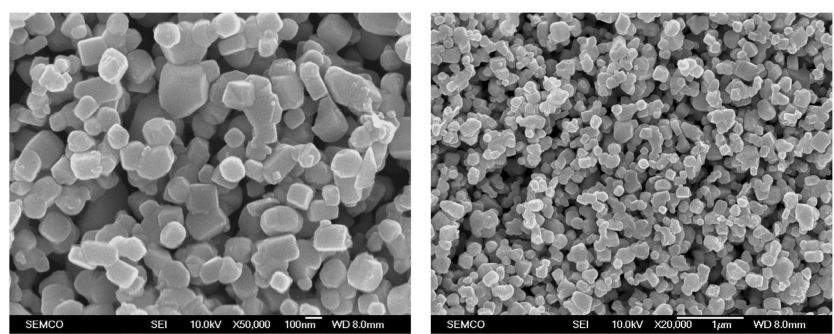

(d) $\mathrm{T}_{\text {calcination }}=990^{\circ} \mathrm{C}$

Fig. 3. FE-SEM micrographs of as-prepared barium titanate powder and calcined powders at various temperature by slurry spray pyrolysis $\left(\mathrm{T}_{\text {reactor }}=900^{\circ} \mathrm{C}\right.$, Air $100 \mathrm{~L} / \mathrm{min}$; $\times 50,000$ (left), $\times 20,000$ (right)).

다. Fig. 3에는 분무열분해 반응기의 온도가 $900^{\circ} \mathrm{C}$ 일 때 합성된 분말과, 이 분말의 하소온도에 따른 하소 후 분말 의 형상을 나타내고 있다. 하소 전 분말은 수 $\mu \mathrm{m}$ 단위로 응집되어 있으나, 하소 후에는 액적 단위의 응집이 깨어 지는 것을 알 수 있다. 또한, 하소 온도가 높아질수록 일 차입자의 성장이 이루어져, $800 \sim 1000^{\circ} \mathrm{C}$ 의 하소에 의해 일 차입자의 크기가 $60 \sim 200 \mathrm{~nm}$ 로 변화됨을 알 수 있다. 이 는 최종 요구되는 입경에 상관없이 분무열분해에 의해 동

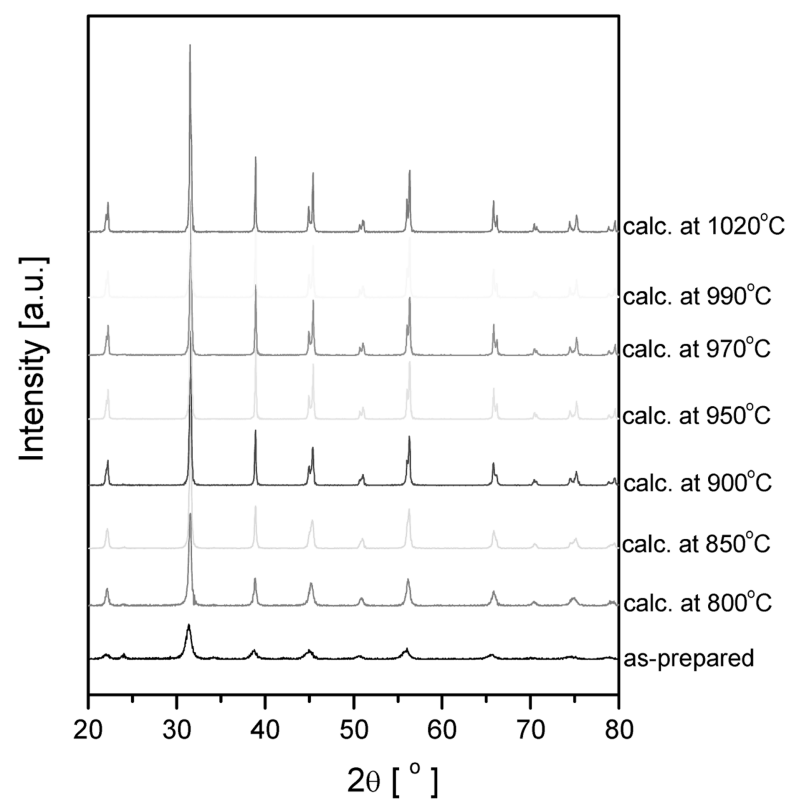

(a)

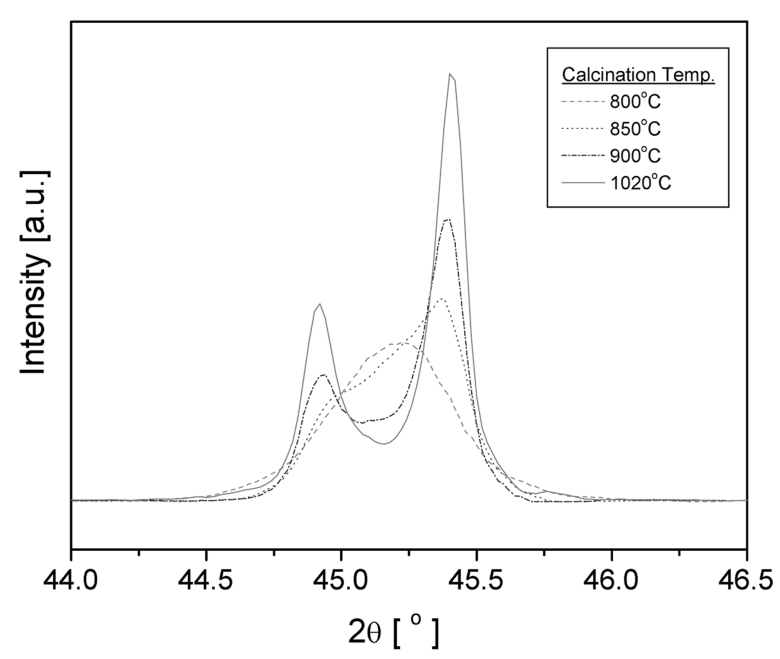

(b)

Fig. 4. XRD pattern of as-prepared barium titanate powder and calcined powder at various temperature by slurry spray pyrolysis $\left(\mathrm{T}_{\text {reactor }}=900^{\circ} \mathrm{C}\right.$, Air $\left.100 \mathrm{~L} / \mathrm{min}\right)$.

일 조건으로 파우더를 합성한 후, 요구되는 입경에 따라 하소 공정에 의해 입경을 제어할 수 있다는 것을 의미하 며, 입경에 따른 생산성의 차이가 없다는 장점 또한 가짐 을 의미한다.

Fig. 4와 Fig. 5 에는 $900^{\circ} \mathrm{C}$ 에서 합성된 분말의 하소 온 도에 따른 결정상 및 결정성과, $\mathrm{FE}-\mathrm{SEM}$ 사진으로부터 측 정된 일차 입자의 크기에 따른 정방화도를 나타내었다. 하소 전 분말의 XRD 결과에는 미반응된 barium carbonate 상이 미량 존재하는 것을 알 수 있으나, 하소 분말에서는 모두 barium titanate로 전환됨을 알 수 있다. 또한, $850^{\circ} \mathrm{C}$ 


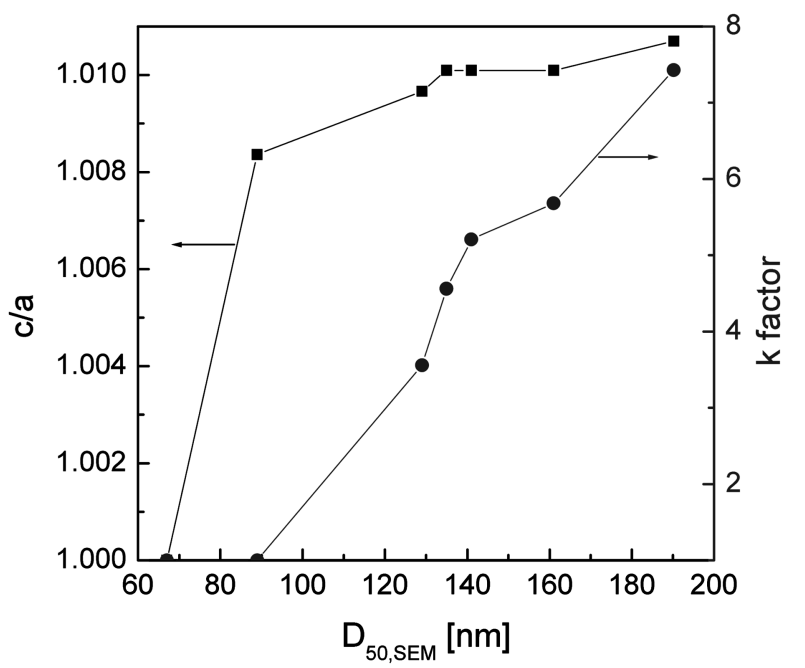

Fig. 5. Tetragonality with changing primary particle size of barium titanate by slurry spray pyrolysis $\left(\mathrm{T}_{\text {reactor }}=900^{\circ} \mathrm{C}\right.$, Air $100 \mathrm{~L} / \mathrm{min}$ ).

이상의 하소 온도부터 cubic 상이 tetragonal 상으로 전환 되기 시작하게 된다. Fig. 5 에 나타내었듯이 $80 \mathrm{~nm}$ 정도 의 입경에서도 약간의 정방화도를 보이기 시작하며, $130 \mathrm{~nm}$ 이상에서는 $\mathrm{c} / \mathrm{a}$ 가 1.01 이상의 값을 갖는다.

반응 메커니즘의 규명을 위해서 분무열분해 반응기의 온도를 변화시켜 가며 합성한 파우더의 물성을 분석하였 다. 반응기의 온도를 $500 \sim 1000^{\circ} \mathrm{C}$ 로 변화시키며 합성한 하 소 전 분말의 $\mathrm{XRD}$ 결과 및 이 분말을 $950^{\circ} \mathrm{C}$ 의 동일 온 도에서 하소한 분말의 결정성을 Fig. 6에 도시하였다. $600^{\circ} \mathrm{C}$ 이하의 합성 온도에서는 거의 barium titanate 상이 존재하지 않고 barium carbonate 상이 주를 이루고 있으 나, $700^{\circ} \mathrm{C}$ 합성온도 이상부터 barium titanate 상이 보이기 시작하여 $1000^{\circ} \mathrm{C}$ 의 합성온도에서는 미반응상이 거의 보 이지 않음을 알 수 있다. 합성온도가 다른 분말들을 동일 하소 조건인 $950^{\circ} \mathrm{C}$ 에서 하소를 하게 되면, Fig. 6 과 같이 $600^{\circ} \mathrm{C}$ 이하의 온도에서 합성한 분말은 cubic 상을 갖는 반면, $700^{\circ} \mathrm{C}$ 이상의 온도에서 합성한 분말은 tetragonal 상 을 갖게 된다. $600^{\circ} \mathrm{C}$ 이하에서 합성한 분말은 분무열분해 반응기를 통과하는 동안 반응은 거의 일어나지 않고 단 순히 용매의 건조만이 이루어진 상태이므로, 이 분말의 하소 공정은 일반적인 고상법에 의한 barium titanate 합 성 공정과 거의 동일하다고 볼 수 있다. 이로부터 고상법 에서와 같이 반응과 하소가 동시에 일어나는 공정보다는 분무열분해법과 같이 순간적인 반응이 이루어진 후 후열 처리를 통해 입자 성장 및 고결정화를 시키는 공정이 바 람직하다고 할 수 있으며, 고상법에서도 하소 공정을 개 선하여 반응과 입자 성장을 분리시킬 수 있다면, 기존의 고상법에 의해 제조되는 분말보다 우수한 물성의 분말을 제조할 수 있다는 가능성을 시사하고 있다.

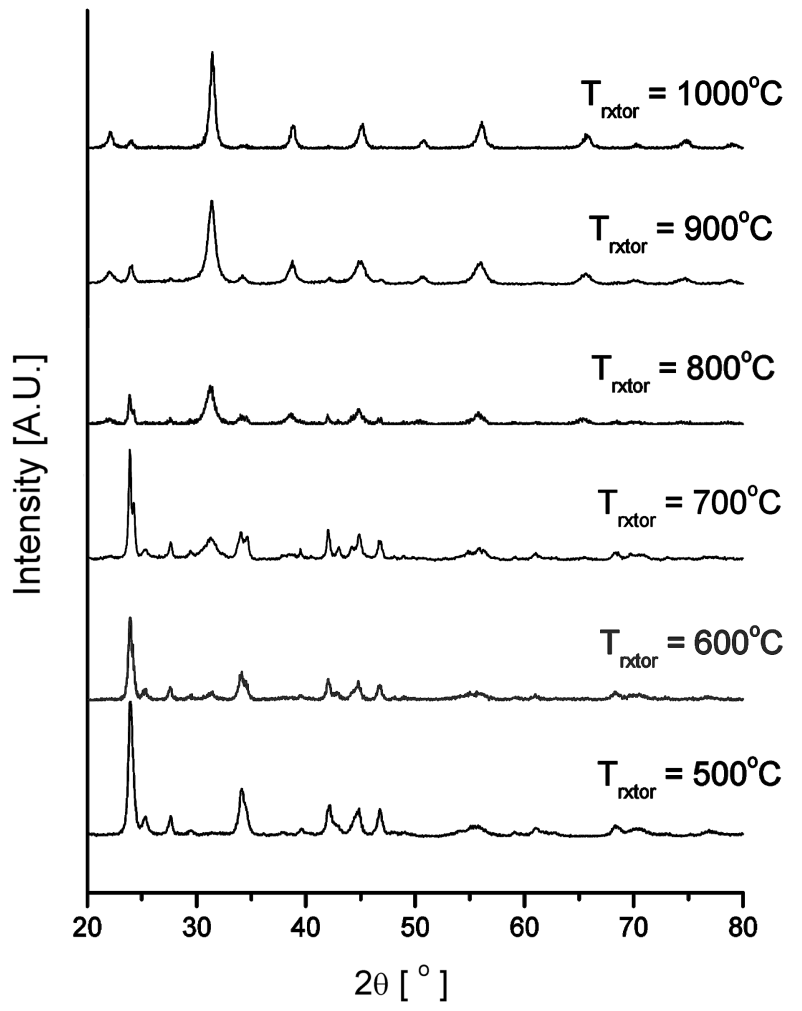

(a) as-prepared

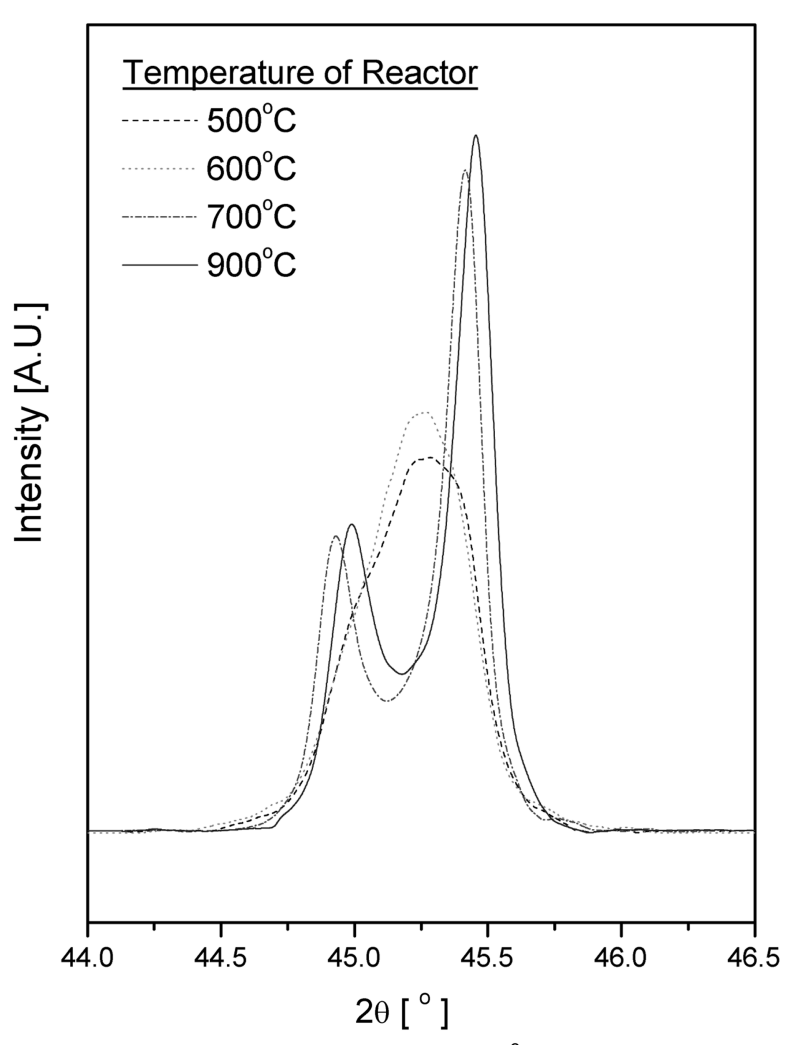

(b) calcined at $950^{\circ} \mathrm{C}$

Fig. 6. XRD spectra with changing the reactor temperature for (a) as-prepared and (b) calcined at $950^{\circ} \mathrm{C}$. 


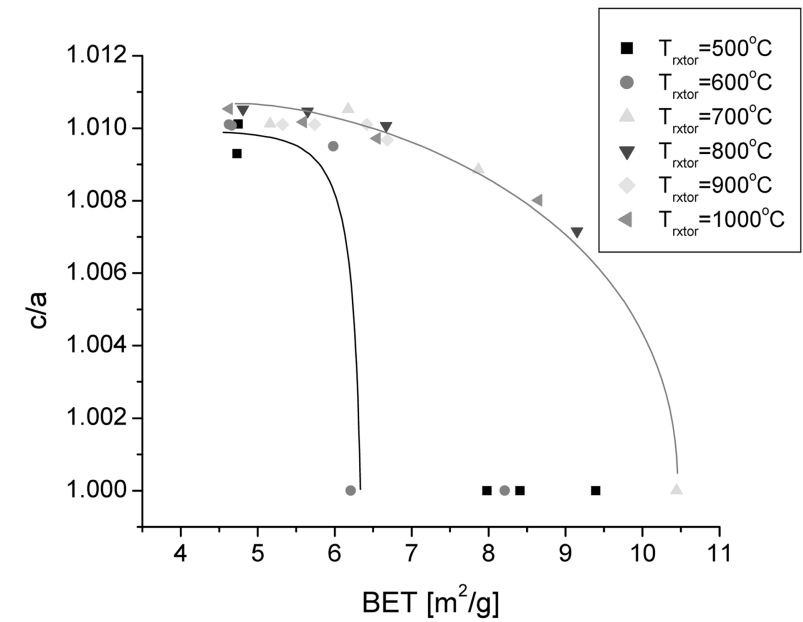

(a) c/a v.s. BET

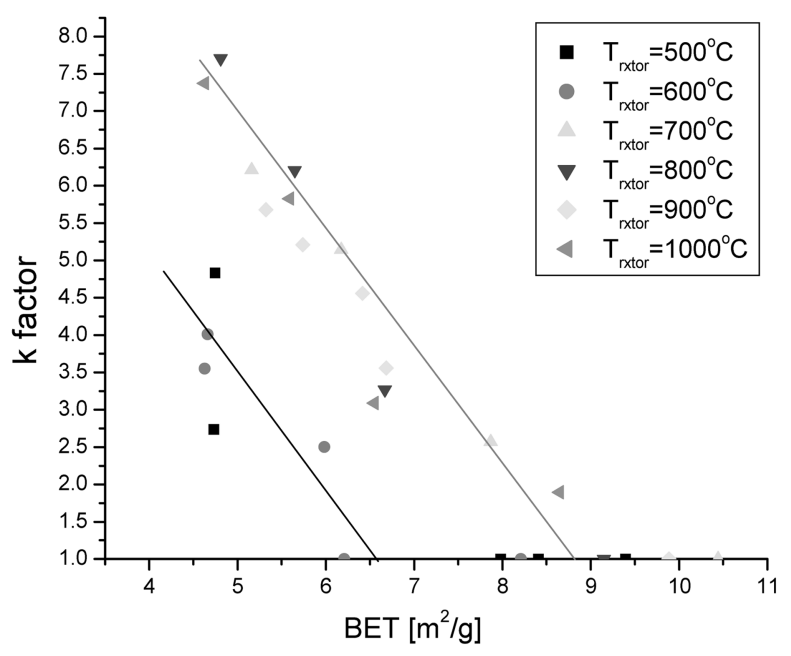

(b) kfactor v.s. BET

Fig. 7. (a) Crystallinity v.s. BET surface area and (b) K factor v.s. BET with temperature of reactor.

합성온도가 각기 다른 분말들을 $800 ~ 1020^{\circ} \mathrm{C}$ 의 범위에 서 하소를 하여, 각 하소 분말들의 BET 비표면적에 따른 $\mathrm{c} / \mathrm{a}$ 및 $\mathrm{k}$ factor를 도시하면 Fig. 7과 같이 합성온도에 따 라 두 부류로 극명하게 나누어지는 것을 알 수 있다. $600^{\circ} \mathrm{C}$ 이하의 온도에서 합성된 분말들은 $6 \mathrm{~m}^{2} / \mathrm{g}$ 이상의 $\mathrm{BET}$ 비표면적을 갖는 미립의 파우더에서는 $\mathrm{c} / \mathrm{a}$ 가 확보되 지 못하며, 그 보다 $\mathrm{BET}$ 비표면적이 작은 분말에서도 $\mathrm{k}$ factor가 상대적으로 낮은 반면에, $700^{\circ} \mathrm{C}$ 이상의 온도에서 합성된 분말들은 $9 \mathrm{~m}^{2} / \mathrm{g}$ 의 높은 BET 비표면적을 갖는 미 립의 파우더에서도 정방화도를 갖게 되며, $\mathrm{k}$ factor 또한 상대적으로 높음을 알 수 있다.

이러한 결정성 측면 뿐 아니라, 분무열분해에 의해 반 응을 시킨 후 하소를 하여 결정성을 확보하는 방법의 장 점으로서, 하소 온도에 따른 $\mathrm{BET}$ 비표면적의 감소(일차

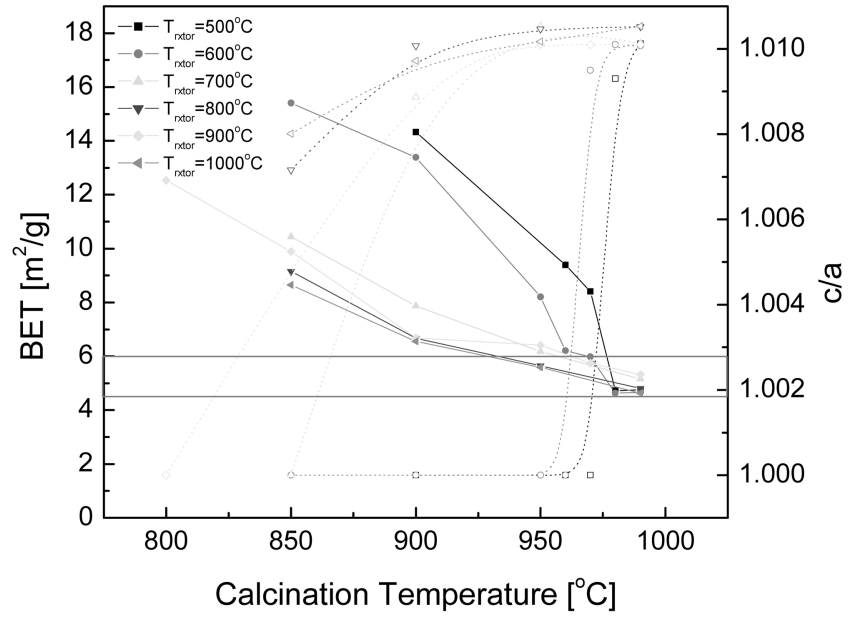

Fig. 8. Effect of calcination temperature on BET surface area (solid line: BET, dot line: c/a).

입자의 성장) 의존성이 낮다는 사실을 Fig. 8 이 보여주고 있다. 단순히 슬러리의 건조만이 일어난 $600^{\circ} \mathrm{C}$ 이하의 온 도에서 합성된 분말의 하소 온도에 따른 $\mathrm{BET}$ 비표면적 의 기울기는 급격한데 반해, barium titanate로의 전환 반 응이 일어난 $700^{\circ} \mathrm{C}$ 이상의 온도에서 합성한 분말의 하소 온도에 따른 $\mathrm{BET}$ 비표면적의 기울기는 매우 완만함을 나 타내고 있다. $600^{\circ} \mathrm{C}$ 이하의 온도에서 합성된 분말은 하소 온도에 따라서 $\mathrm{BET}$ 비표면적이 급격히 변할 뿐만 아니 라, 하소온도가 $950^{\circ} \mathrm{C}$ 이하로 낮아지게 되면 정방화도 또 한 급격히 떨어진다. 하소 온도에 따른 비표면적의 의존 성이 작다는 것은 하소 공정의 윈도우가 넓다는 것을 의 미하며, 이러한 공정에서는 하소로(kiln)의 온도편차 관리 가 상대적으로 덜 엄격하여도 되며, 대량으로 하소를 하 여도 lot 내의 온도 불균일에 의해 일어나는 분말 특성의 편차가 작고, lot 간의 분말 특성 또한 편차가 작다는 것 을 의미한다.

\section{2. 열분해 반응의 kinetics 해석}

Fig. 9에는 분무액으로 사용되는 슬러리를 건조만 시킨 후, 그 건조된 원료 혼합 분말의 $\mathrm{TGA}$ 곡선을 나타내고 있다. $200 \sim 300^{\circ} \mathrm{C}$ 에서 보이는 약간의 중량 감소는 분산제 의 제거에 의한 것이며, 그 이외에 Region I과 Region II 의 큰 폭의 중량감소가 $\mathrm{BaCO}_{3}$ 의 분해에 의해 일어나는 것으로 볼 수 있다. 분해반응이 이와 같이 두 가지로 나 뉘어지는 것으로 보아, $\mathrm{BaCO}_{3}$ 및 $\mathrm{TiO}_{2}$ 로부터 $\mathrm{BaTiO}_{3}$ 로 전 환되는 반응에는 두 가지 mechanism이 존재한다는 것을 추정할 수 있다. Region I과 II에 대해서 각각 Table 2의 kinetic equation들을 사용하여 Arrhenius plot을 하여 직선 을 나타내는 reaction model을 찾으면, 반응 mechanism을 규명할 수 있다.

고체상의 분해 반응식은 다음과 같이 표현할 수 있다. 


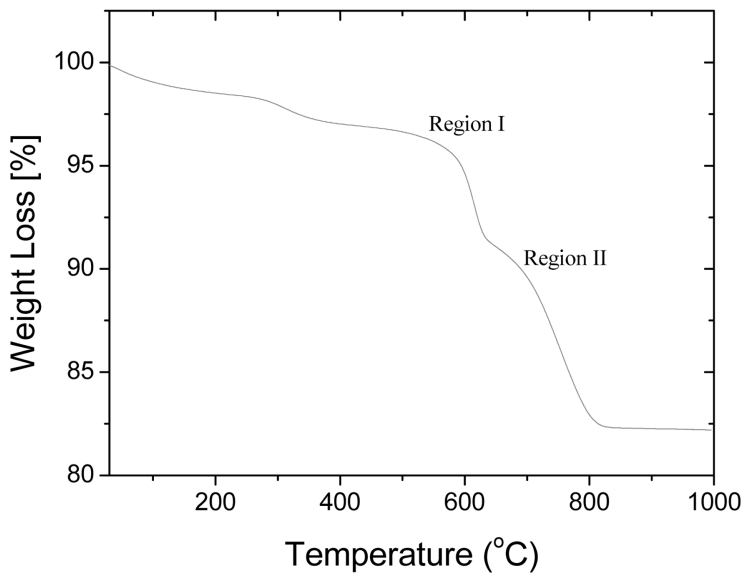

Fig. 9. TGA curve of powder mixture of $\mathrm{BaCO}_{3}-\mathrm{TiO}_{2}$.

$$
\frac{d \alpha}{d t}=k f(\alpha)
$$

여기서, $\alpha$ 는 초기 반응물에 대한 반응된 분율이며, $k$ 는 반응상수로서 다음과 같이 Arrhenius 식으로 표현된다.

$$
k=A e^{-E / R T}
$$

승온속도를 $\beta(=\mathrm{dT} / \mathrm{dt})$ 라 하면, 식 (1)은 다음과 같이 표 현된다.

$$
\beta \frac{d \alpha}{d T}=A e^{-E / R T} f(\alpha)
$$

Table 2의 $\mathrm{F}(\alpha)$ 와 식 (3)의 $f(\mathrm{a})$ 는 다음의 관계식을 갖는다.

$$
f(\alpha)=\frac{1}{\frac{d F(\alpha)}{d \alpha}}
$$

\begin{tabular}{|c|c|c|}
\hline Reaction model & $\mathrm{F}(\alpha)$ & Symbol \\
\hline One-dimensional diffusion & $\alpha^{2}$ & $\mathrm{D}_{1}$ \\
\hline Two-dimensional diffusion & $\alpha+(1-\alpha) \ln (1-\alpha)$ & $\mathrm{D}_{2}$ \\
\hline $\begin{array}{l}\text { Jander equation, } \\
\text { three-dimensional diffusion }\end{array}$ & {$\left[1-(1-\alpha)^{1 / 3}\right]^{2}$} & $\mathrm{D}_{3}$ \\
\hline $\begin{array}{l}\text { Ginstling-Brounshtein equation, } \\
\text { three-dimensional diffusion }\end{array}$ & $\begin{array}{l}(1-2 / 3 \alpha) \\
-(1-\alpha)^{2 / 3}\end{array}$ & $\mathrm{D}_{4}$ \\
\hline $\begin{array}{l}\text { Two-dimensional phase } \\
\text { boundary reaction }\end{array}$ & {$\left[1-(1-\alpha)^{1 / 2}\right]$} & $\mathrm{R}_{2}$ \\
\hline $\begin{array}{l}\text { Three-dimensional phase } \\
\text { boundary reaction }\end{array}$ & {$\left[1-(1-\alpha)^{1 / 3}\right]$} & $\mathrm{R}_{3}$ \\
\hline First-order kinetics & {$[-\ln (1-\alpha)]$} & $\mathrm{F}_{1}$ \\
\hline $\begin{array}{l}\text { Random nucleation: } \\
\text { Avrami equation }\end{array}$ & {$[-\ln (1-\alpha)]^{1 / 2}$} & $\mathrm{~A}_{2}$ \\
\hline $\begin{array}{l}\text { Random nucleation: } \\
\text { Erofeev equation }\end{array}$ & {$[-\ln (1-\alpha)]^{1 / 3}$} & $\mathrm{~A}_{3}$ \\
\hline
\end{tabular}

Table 2. Kinetic Equations Examined in This Work ${ }^{7,8)}$
Table 2의 각 모델에 대해서 식 (4)로부터 $f(\alpha)$ 를 구한 후, 식 (3)에 대입하여 직선을 나타내는 Arrhenius plot을 찾으면 Fig. 10과 같다. 즉, Region I은 random nucleation (Erofeev equation: $\mathrm{A}_{3}$ ) model을 따르며, Region II는 Three dimensional diffusion (Ginstling-Brounshtein equation: $\mathrm{D}_{4}$ ) model을 따른다.

기존의 연구에 따르면, $\mathrm{BaCO}_{3}$ 와 $\mathrm{TiO}_{2}$ 로부터 $\mathrm{BaTiO}_{3}$ 를 형성하는 반응은 다음의 네 단계로 이루어진다는 사실이 널리 받아들여지고 있다. ${ }^{9,10)}$

$$
\begin{aligned}
& \mathrm{BaCO}_{3} \leftrightarrow \mathrm{BaO}+\mathrm{CO}_{2} \\
& \mathrm{BaO}+\mathrm{TiO}_{2} \rightarrow \mathrm{BaTiO}_{3}
\end{aligned}
$$

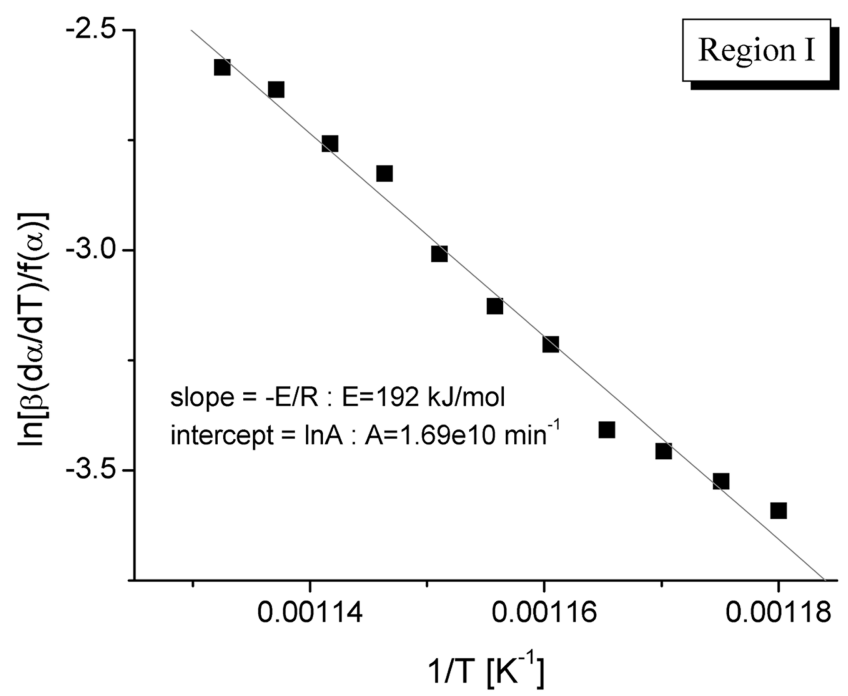

(a) Region I: Random nucleation (Erofeev equation) assumption.

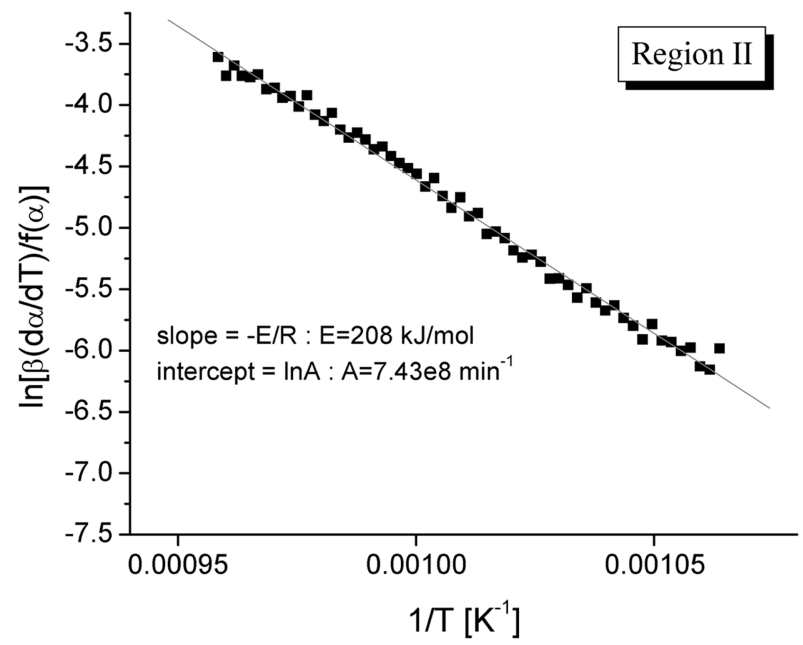

(b) Region II: Three dimensional diffusion (GinstlingBrounshtein equation) assumption.

Fig. 10. Arrhenius plot of (a) region I and (b) II. 


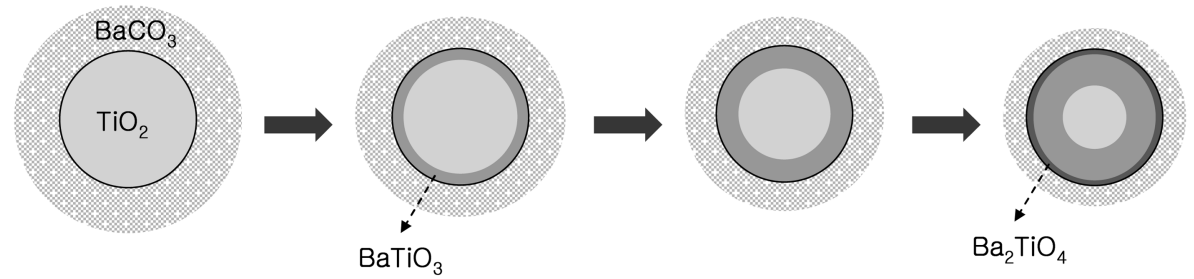

(a) Region I

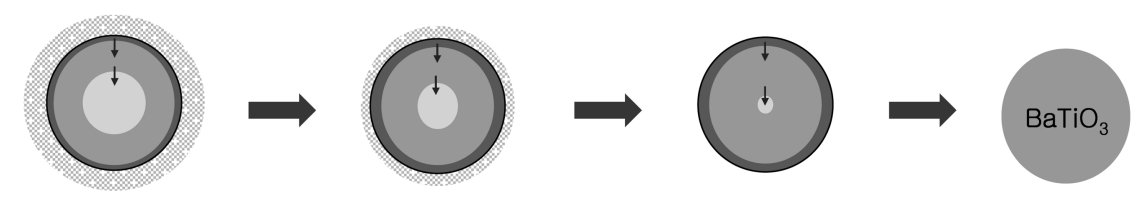

(b) Region II

Fig. 11. Model of thermal decomposition reaction of $\mathrm{BaCO}_{3}$ and $\mathrm{TiO}_{2}$, (a) Region I and (b) Region II.

$$
\begin{aligned}
& \mathrm{BaTiO}_{3}+\mathrm{BaO} \rightarrow \mathrm{Ba}_{2} \mathrm{TiO}_{4} \\
& \mathrm{Ba}_{2} \mathrm{TiO}_{4}+\mathrm{TiO}_{2} \rightarrow 2 \mathrm{BaTiO}_{3}
\end{aligned}
$$

Fig. 10 에 의해 규명된 mechanism에 의하면, Region I은 $\mathrm{BaO}$ 가 $\mathrm{TiO}_{2}$ 나 $\mathrm{BaTiO}_{3}$ 와 반응하여 barium titanate를 형성 해가며 핵이 성장하는 (6), (7)의 단계가 율속단계인 것으 로 추정되며, Region II에서는 일차입자의 표면층에 barium titanate가 포화되어 원활히 (6), (7)의 반응이 일어나지 못 하고, (8)의 과정에 의해 barium titanate로 형성되어 있는 표면층으로부터 $\mathrm{TiO}_{2}$ 로 구성되어 있는 core부분으로의 $\mathrm{Ba}$ 의 고상확산이 이루어져야만 (6), (7)의 반응이 일어나는 단계로서, 이 단계는 diffusion-controlled step으로 보여진 다. 이러한 $\mathrm{BaTiO}_{3}$ 형성 과정을 Fig. 11에 간략하게 도시 하였다.

분무열분해 반응기의 합성온도를 변화시켜가며 제조된

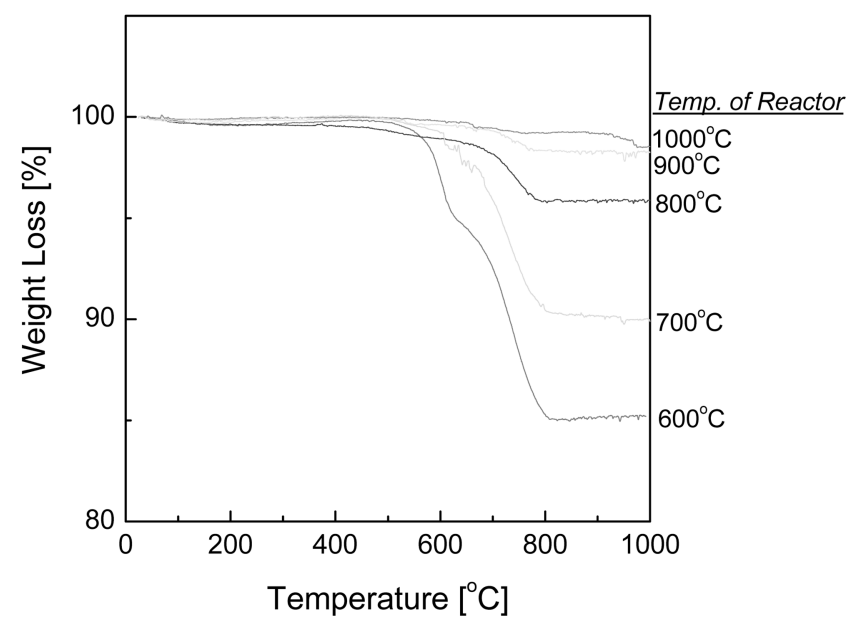

Fig. 12. TGA curves of as-prepared powder with changing temperature of reactor by slurry spray pyrolysis.
하소 전 분말의 TGA 곡선을 Fig. 12에 도시하였다. $600^{\circ} \mathrm{C}$ 이하의 합성분말은 Fig. 9의 슬러리 건조분말과 같이 region $\mathrm{I}$ 과 $\mathrm{II}$ 의 중량 감소 구간이 나타나지만, $700^{\circ} \mathrm{C}$ 이상에서 합성한 분말에서는 region I의 중량감소 구간이 나타나지 않는다. 즉, $700^{\circ} \mathrm{C}$ 이상에서 합성된 분말은 하소 공정 중 의 미량의 미반응물들의 분해반응은 diffusion-controlled process로만 진행됨을 알 수 있다. 이러한 분해반응 메카 니즘의 차이는, 결정성이나 하소 윈도우 측면에서 큰 차 이를 보이는 두 부류의 합성 조건이 나타나는 하나의 큰 이유가 될 것이나, 하소 공정 중에 일어나는 입자 성장 과정을 동시에 복합적으로 고려해야만 정확한 해석이 가 능할 것이다.

\section{4. 결 론}

고상원료의 슬러리를 도입하여 새로운 분무열분해 공 정을 설계하고 이로부터 고성능의 초미립 barium titanate 분말을 제조하기 위한 본 연구로부터 아래와 같은 결론 을 얻었다.

- 본 연구에서 제안된 슬러리 분무열분해법은 용액 분무 열분해법 보다 $10 \sim 15$ 배의 월등히 높은 생산성을 가지 며 고결정성의 초미립 barium titanate 분말의 제조가 가 능하였다.

- 분무열분해 합성 온도는 $700^{\circ} \mathrm{C}$ 이상이어야만, 하소 과 정 중의 미반응물의 분해반응은 diffusion-controlled process로만 진행되며, 이 경우에 보다 미립에서 높은 정방 화도를 얻을 수 있다.

- 분무열분해 합성분말의 하소 공정은 일반적인 고상법의 경우에 비해 온도에 따른 하소 분말 특성의 의존성이 현격히 낮다.

이상을 종합할 때, 고상 슬러리를 원료로 분무열분해 
합성 후, box kiln이나 tunnel kiln 등 기존의 산업용 대량 하소 설비를 이용하게 되면, 고결정성 미립 barium titanate 분말 제조의 대량 생산이 가능하며, 고상법에서도 하소 공정을 개선하여 반응과 입자 성장을 분리시킬 수만 있 다면, 기존의 고상법에 의해 제조되는 분말보다 우수한 물성의 분말을 제조할 수 있을 것이다.

\section{REFERENCES}

1. W. J. Tseng and S.-Y. Lin, "Effect of Polymeric Surfactant on Flow Behaviors of Nickel-ethanol-isopropanol Suspensions," Mater. Sci. Eng. A, 362 [1-2] 160-66 (2003).

2. C. Gomez-Yañez, C. Benitez, and H. Balmori-Ramirez, "Mechanical Activation of the Synthesis Reaction of $\mathrm{BaTiO}_{3}$ from a Mixture of $\mathrm{BaCO}_{3}$ and $\mathrm{TiO}_{2}$ Powders," Ceramics International, 26 [3] 271-77 (2000).

3. J.-M. Hwu, W.-H. Yu, W.-C. Yang, Y.-W. Chen, and Y.-Y. Chou, "Characterization of Dielectric Barium Titanate Powders Prepared by Homogeneous Precipitation Chemical Reaction for Embedded Capacitor Applications," Mater. Res. Bulletin, 40 [10] 1662-79 (2005).

4. X. Xing, J. Deng, J. Chen, and G Liu, "Phase Evolution of Barium Titanate from Alkoxide Gel-derived Precursor," $J$.
Alloys and Compounds, 384 [1-2] 312-17 (2004).

5. D. F. K. Hennings, C. Metzmacher, and B. S. Schreinemacher, "Defect Chemistry and Microstructure of Hydrothermal Barium Titanate," J. Am. Ceram. Soc., 84 [1] 179-82 (2001).

6. K. K. Lee, Y. C. Kang, K. Y. Jung, and J. H. Kim, "Preparation of Nano-sized $\mathrm{BaTiO}_{3}$ Particle by Citric Acidassisted Spray Pyrolysis," J. Alloy and Compounds, 395 [12] 280-85 (2005).

7. X. Zhao, B. Zheng, C. Li, and H. Gu, "Acetate-derived ZnO Ultrafine Particles Synthesized by Spray Pyrolysis," Powder Tech., 100 [1] 20-3 (1998).

8. Z. A. Omran, M. A. Mousa, A. A. A. Fattah, and E.-H. M. Diefallah, "Kinetic Analysis of Thermal Decomposition Reactions : Part IV: Kinetics of Formation of Barium Titanate in Crystalline Mixtures of Barium Carbonate and Titanium Dioxide," Thermochimica Acta, 145 271-79 (1989).

9. E. Brzozowski and M. S. Castro, "Synthesis of Barium Titanate Improved by Modifications in the Kinetics of the Solid State Reaction," J. Eur. Ceram. Soc., 20 [14-5] $2347-$ 51 (2000).

10. J. C. Niepce and G. Thomas, "About the Mechanism of the Solid-way Synthesis of Barium Metatitanate. Industrial Consequences," Solid State Ionics, 43 69-76 (1990). 